\title{
Herbidospora gen. nov., a New Genus of the Family Streptosporangiaceae Goodfellow et al. 1990 TAKUJI KUDO, ${ }^{1 *}$ TAKASHI ITOH, ${ }^{1}$ SHINJI MIYADOH, ${ }^{2}$ TAKASHI SHOMURA, ${ }^{2}$ AND AKIO SEINO ${ }^{1} \dagger$ \\ Japan Collection of Microorganisms, The Institute of Physical and Chemical Research (RIKEN), Wako, Saitama 351-01, ${ }^{1}$ and Pharmaceutical Research Center, Meiji Seika Kaisha Ltd.,
} Kohoku-ku, Yokohama, Kanagawa 222, ${ }^{2}$ Japan

\begin{abstract}
Eight actinomycete strains originally isolated from soil and plant samples were studied to determine their taxonomic status. All isolates produced branching substrate mycelia, but no distinct aerial hyphae. Relatively short chains of nonmotile spores (10 to 30 spores per chain) were borne on the tips of sporophores arising directly from the agar surface. The chemotaxonomic characteristics of the isolates, with the exception of the menaquinone profile, coincided with those of members of the family Streptosporangiaceae Goodfellow, Stanton, Simpson, and Minnikin 1990. Furthermore, the results of a phylogenetic analysis performed with 5S rRNA support the conclusion that the isolates should be classified in this family. The isolates differed from members of the constituent genera of the Streptosporangiaceae in morphological characteristics and menaquinone composition. Therefore, we propose a new genus for the strains, Herbidospora. The type species and type strain are Herbidospora cretacea sp. nov. and strain K-319 (= JCM 8553), respectively.
\end{abstract}

The tentative name "maduromycete group" was used by Goodfellow and Cross in 1984 (12) for the chemotaxonomically defined actinomycete group which has cell wall type III and whole-cell sugar pattern B of Lechevalier and Lechevalier (28). At that time, this group included the genera Actinomadura, Microbispora, Microtetraspora, Planobispora, Planomonospora, Spirillospora, and Streptosporangium. Subsequently, the genera Actinomadura and Spirillospora were eliminated from this group (11) on the basis of cellular lipid profiles $(1,2,23,29)$ and phylogenetic relationships (9). In 1990, the family Streptosporangiaceae was proposed by Goodfellow et al. (13) for the redefined maduromycete group. The taxonomic properties of the genera in this family are similar to each other. These organisms are characterized by the following common features. Substrate and aerial mycelia are well developed and branched. Spore chains or sporangia are formed on the tips of sporophores branching from the aerial hyphae. meso-Diaminopimelic acid is present in the cell walls, but glycine is not (wall chemotype III). The $N$-acyl type of muramic acid in the cell walls is an acetyl type (21). The cellular fatty acids consist of straight, iso-branched, and 10-methylated acids $(23,25)$. The predominant isoprenoid quinones are unsaturated, dihydrogenated, and tetrahydrogenated menaquinones with nine isoprene units [MK-9, MK-9( $\left.\mathrm{H}_{2}\right)$, and MK-9( $\left.\mathrm{H}_{4}\right)$, respectively] $(1,2,23,25,26,32)$; the tetrahydrogenation occurs at the sites of isoprene units III (the third unit from the 2-methyl-1,4-naphthoquinone moiety) and VIII [MK9(III,VIII- $\left.\left.\mathrm{H}_{4}\right)\right](4,25)$. Phosphatidylethanolamine and glucosamine-containing phospholipids are present as diagnostic polar lipids (phospholipid type PIV of Lechevalier et al. [27]). At present, these genera are distinguished by morphological features, including the existence of sporangia and the number of spores per sporangium or chain.

We isolated eight actinomycete strains with unusual morphological features from soil and plant samples in Japan.

\footnotetext{
* Corresponding author.

$\dagger$ Present address: Research Center for Biological Function, The Kitasato Institute, Minato-ku, Tokyo 108, Japan.
}

Although these isolates differed in morphology from the previously described members of the family Streptosporangiaceae, all of their chemotaxonomic characteristics, except their menaquinone profiles, agreed with those of members of this family. Furthermore, the results of a phylogenetic analysis performed with 5S rRNA sequences supported the classification of these organisms in the Streptosporangiaceae. In this paper we describe our isolates as members of a new species of a new genus in the family Streptosporangiaceae on the basis of morphological, chemical, physiological, and biochemical characteristics, levels of DNA-DNA relatedness, and $5 \mathrm{~S}$ rRNA sequences. The names Herbidospora gen. nov. and Herbidospora cretacea sp. nov. are proposed for the new genus and species.

\section{MATERIALS AND METHODS}

Bacterial strains. Eight strains isolated from plant and soil samples in Japan (Table 1) were investigated. The plant samples from which strains I-186, I-385, I-404, and I-405 were isolated were desiccated at $28^{\circ} \mathrm{C}$ for at least 1 week and were ground with a blender after sterile water was added. The suspension was incorporated into yeast extract agar containing $0.2 \mathrm{~g}$ of yeast extract (Difco Laboratories, Detroit, Mich.), $50 \mathrm{mg}$ of cycloheximide, $50 \mathrm{mg}$ of nystatin, and $15 \mathrm{~g}$ of agar in $1,000 \mathrm{ml}$ of distilled water, and this preparation was poured into a petri dish. After incubation at $28^{\circ} \mathrm{C}$ for more than 2 weeks, colonies that appeared were picked with a sterile needle under a stereomicroscope. Strains K-83, $\mathrm{K}-319^{\mathrm{T}}$ ( $\mathrm{T}=$ type strain), SF2625, and SF2742 were isolated by the dilution agar plating method by using yeast extractstarch agar ( $2 \mathrm{~g}$ of yeast extract [Difco], $10 \mathrm{~g}$ of starch, and $15 \mathrm{~g}$ of agar in 1,000 ml of distilled water; $\mathrm{pH} 7.3$ ) and the humic acid-vitamin agar of Hayakawa and Nonomura (15).

The following type strains were used for the comparative studies: Actinomadura madurae JCM 7436, Microbispora rosea JCM 3006, Microtetraspora glauca JCM 3300, Nocardiopsis dassonvillei JCM 7437, Planobispora longispora JCM 3092, Planomonospora parontospora JCM 3093, Planomonospora venezuelensis JCM 3167, Saccharothrix aus- 
TABLE 1. List of the isolates used in this study and their sources

\begin{tabular}{|c|c|}
\hline & Source \\
\hline & Decayed leaves collected in Saitama, Japan \\
\hline $\begin{array}{l}\mathrm{I}-186(=\mathrm{JC} \\
\mathrm{I}-385(=\mathrm{JC} C\end{array}$ & ..Bark of Japanese red pine (Pinus densiflora) collected in Saitama, Japan \\
\hline \multirow{2}{*}{$\begin{array}{l}\mathrm{I}-404(=\mathrm{JCM} 8550) \ldots \\
\mathrm{I}-405(=\mathrm{JCM} 8551) \ldots\end{array}$} & ..Petal of daisy fleabane (Erigeron annuus) collected in Saitama, Japan \\
\hline & ..Petal of daisy fleabane (Erigeron annuus) collected in Saitama, Japan \\
\hline \multirow{2}{*}{ K-83 (= JCM 8552) $\ldots$} & ..Soil collected in Saitama, Japan \\
\hline & ..Soil collected in Saitama, Japan \\
\hline SF2625 (= JCM 8554) & . Soil collected in Tokyo, Japan \\
\hline \multicolumn{2}{|c|}{ SF2742 $(=$ JCM 8555) .................................................. Soil collected in Okinawa, Japan } \\
\hline
\end{tabular}

a JCM, Japan Collection of Microorganisms, RIKEN, Wako, Saitama, Japan.

traliensis JCM 3370, Streptosporangium roseum JCM 3005, and Streptosporangium viridogriseum JCM 3282.

Morphology. Cultures were grown on oatmeal agar (International Streptomyces Project [ISP] medium 3 ) for 14 days at $28^{\circ} \mathrm{C}$ and observed with a light microscope and a scanning electron microscope (model JEM 100C-ASID; JEOL, Ltd., Tokyo, Japan). Samples for scanning electron microscopy were prepared by cutting an agar block on which the culture grew, fixing it in osmium tetroxide vapor at room temperature for $2 \mathrm{~h}$, and then freeze-drying it. The specimen was sputter-coated with gold under a vacuum.

Cultural, physiological, and biochemical characteristics. Cultural characteristics were tested by using 21-day cultures grown at $28^{\circ} \mathrm{C}$ on various agar media (Table 2). The Color Harmony Manual (18) was used to determine colony colors. Decomposition of various compounds was examined by using the basal media of Gordon et al. (14) and Goodfellow (10). Utilization of carbohydrates as sole carbon sources was tested by using yeast nitrogen base without amino acids (Difco) as a basal medium and the method described by Stevenson (40). Utilization of organic acids was examined on the defined medium of Gordon et al. (14) supplemented with the vitamin B complex solution used in humic acid-vitamin agar (15). The requirements for vitamins (each at a concentration of $0.5 \mu \mathrm{g} / \mathrm{ml}$ ) were examined on a defined medium containing $10 \mathrm{~g}$ of glucose, $2 \mathrm{~g}$ of vitamin assay Casamino Acids (Difco), $0.5 \mathrm{~g}$ of $\mathrm{KCl}, 0.5 \mathrm{~g}$ of $\mathrm{MgSO}_{4} \cdot 7 \mathrm{H}_{2} \mathrm{O}, 0.3 \mathrm{~g}$ of $\mathrm{K}_{2} \mathrm{HPO}_{4}$, and $15 \mathrm{~g}$ of purified agar (Difco) in 1,000 ml of distilled water $(\mathrm{pH}$ 7.2). Formation of a melaninlike pigment was examined on peptone-yeast extract-iron agar (ISP medium 6) and tyrosine agar (ISP medium 7). Growth temperature was determined on yeast extract-starch agar by using a temperature gradient incubator (model TN-3; Advantec Toyo, Tokyo, Japan). Bennett's agar medium was used to determine tolerance to sodium chloride, lysozyme, and antibiotics (Table 3).

Chemotaxonomy. Freeze-dried cells for chemotaxonomic analyses were obtained from cultures grown in yeast extractglucose broth (containing $10 \mathrm{~g}$ of yeast extract and $10 \mathrm{~g}$ of D-glucose in 1,000 ml of distilled water; $\mathrm{pH} \mathrm{7.2)} \mathrm{on} \mathrm{a} \mathrm{rotary}$ shaker at $30^{\circ} \mathrm{C}$. Cell wall peptidoglycan was prepared and hydrolyzed by the methods of Kawamoto et al. (21), and the amino acid composition was analyzed with an automatic amino acid analyzer (model 835; Hitachi Ltd.). The isomers of diaminopimelic acid in cell walls were determined by the method of Staneck and Roberts (39), and whole-cell sugars were detected by the methods of Staneck and Roberts (39) and Meyertons et al. (30). The cell wall acyl type was determined by the method of Uchida and Aida (45). Phospholipids in cells were extracted and identified by the method of Minnikin et al. (31). Methyl esters of cellular fatty acids were prepared by the direct transmethylation method with methanolic hydrochloride (41) and were analyzed by using a gas-liquid chromatograph (model GC-7A; Shimadzu Corp., Kyoto, Japan) equipped with a fused-silica capillary column coated with OV-1 $(0.24 \mathrm{~mm}$ by $25 \mathrm{~m}$; Shimadzu Corp.). The temperature of the column was programmed to increase from 180 to $220^{\circ} \mathrm{C}$ at a rate of $1^{\circ} \mathrm{C} / \mathrm{min}$, and the injector was kept at $250^{\circ} \mathrm{C}$. The peaks were identified by comparison with authentic samples and by using a gas-liquid chromatograph-mass spectrometer (model QP-1000; Shimadzu Corp.) equipped with the column described above. The quantitative fatty acid data were numerically analyzed by using the NTSYS-pc program package (Applied Biostatis-

TABLE 2. Cultural characteristics of $H$. cretacea

\begin{tabular}{|c|c|c|c|c|}
\hline \multirow{2}{*}{ Agar medium $^{a}$} & \multicolumn{2}{|c|}{ Strain K-319 } & \multicolumn{2}{|c|}{ Strain SF2742 } \\
\hline & $\begin{array}{c}\text { Growth } \\
\text { (reverse side color) }^{c}\end{array}$ & $\begin{array}{c}\text { Sporulation } \\
\text { (aerial mass color) }^{c}\end{array}$ & $\begin{array}{c}\text { Growth } \\
\text { (reverse side color) }^{c}\end{array}$ & $\begin{array}{c}\text { Sporulation } \\
\text { (aerial mass color) }^{c}\end{array}$ \\
\hline Bennett & Good (light amber [3ic]) & Poor (white) & Good (camel [3ie]) & None \\
\hline Glucose-asparagine & None to poor (colorless) & None & None to poor (colorless) & None \\
\hline Glycerol-asparagine & Poor (colorless) & None & Poor (colorless) & None \\
\hline Hickey-Tresner & Good (cinnamón [3le]) & Poor (white) & Good (light amber [3ic]) & Poor (white) \\
\hline Inorganic salts-starch & Poor (colorless) & None & Poor (colorless) & None \\
\hline Oatmeal & Good (bamboo [2gc]) & Good (white) & Good (light $\tan [3 \mathrm{gc}]$ ) & Good (bamboo [2fb]) \\
\hline Oatmeal-nitrate & Moderate (colorless) & Good (white) & Moderate (camel [3ie]) & Good (bamboo [2fb]) \\
\hline Sucrose-nitrate & None to poor (colorless) & None & None to poor (colorless) & None \\
\hline Yeast extract-malt extract & Good (mustard gold [2pe]) & Poor (white) & Good (cinnamon [3le]) & Poor (white) \\
\hline Yeast extract-starch & Good (light $\tan [3 \mathrm{gc}]$ ) & Moderate (white) & Good (camel [3ie]) & Good (bamboo [2fb]) \\
\hline
\end{tabular}

${ }^{a}$ No diffusible pigments were produced on any of the media.

${ }^{b}$ All of the other isolates except strain SF2742 have characteristics similar to those of strain K-319 .

c Color names and designations were taken from the Color Harmony Manual (18). 
TABLE 3. Physiological and biochemical characteristics of $H$. cretacea $^{a}$

\begin{tabular}{|c|c|}
\hline Characteristic & Reaction $^{b}$ \\
\hline \multicolumn{2}{|l|}{ Decomposition of: } \\
\hline Adenine............ & - \\
\hline Arbutin.. & - \\
\hline Casein .... & + \\
\hline DNA & + \\
\hline Esculin & + \\
\hline 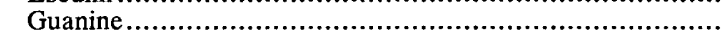 & - \\
\hline Hypoxanthine ........................................... & + \\
\hline 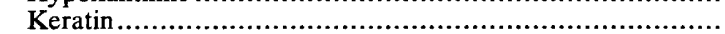 & - \\
\hline Starch .... & + \\
\hline Testosterone.. & $\mathrm{v}$ \\
\hline Tyrosine. & - \\
\hline Urea . & $\mathrm{v}$ \\
\hline Xanthine. & - \\
\hline \multicolumn{2}{|l|}{$\begin{array}{l}\text { Growth on the following compounds as sole carbon } \\
\text { sources }(1 \%, w t / v o l):\end{array}$} \\
\hline 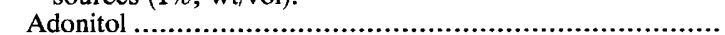 & - \\
\hline 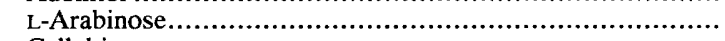 & + \\
\hline 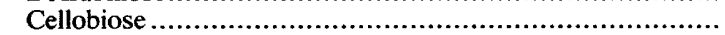 & + \\
\hline (1) & - \\
\hline Dulcitol .. & - \\
\hline 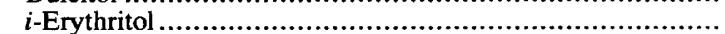 & - \\
\hline 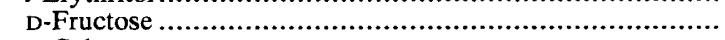 & + \\
\hline (2) & + \\
\hline D-Glu & + \\
\hline ......... & - \\
\hline myo & - \\
\hline Malto & + \\
\hline D-Mar & + \\
\hline 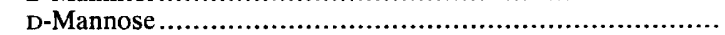 & + \\
\hline ............ & - \\
\hline 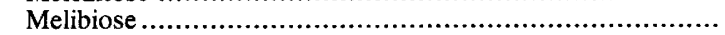 & \pm \\
\hline ....................... & - \\
\hline 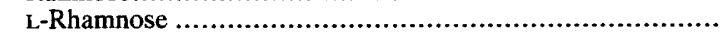 & $\mathbf{v}$ \\
\hline g. & + \\
\hline Salic & $\mathbf{v}$ \\
\hline (........................................ & \pm \\
\hline ................... & + \\
\hline (1) & + \\
\hline 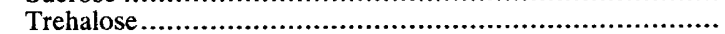 & $\mathrm{v}$ \\
\hline 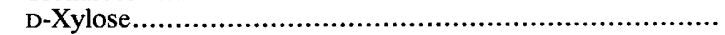 & + \\
\hline \multicolumn{2}{|l|}{ Utilization of: } \\
\hline Benzoic acid.. & - \\
\hline (n. & - \\
\hline cid & + \\
\hline (1) & + \\
\hline 대. & + \\
\hline (........................... & - \\
\hline (1) & - \\
\hline 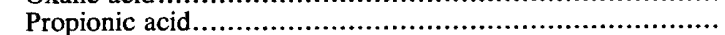 & - \\
\hline 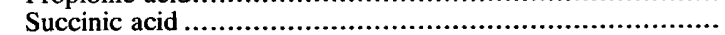 & + \\
\hline 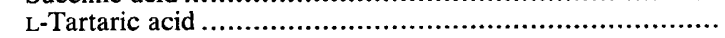 & - \\
\hline \multicolumn{2}{|l|}{ Requi } \\
\hline oic aci & - \\
\hline Biot & - \\
\hline & - \\
\hline ............. & - \\
\hline (.................................... & - \\
\hline (2) & - \\
\hline 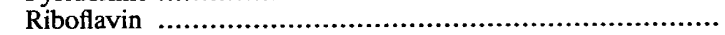 & - \\
\hline Thiamine . & + \\
\hline \multicolumn{2}{|l|}{ Formation of melaninlike pigment in: } \\
\hline Peptone-yeast extract-iron agar... & NG \\
\hline \multirow{2}{*}{\multicolumn{2}{|c|}{ Growth in the presence of: }} \\
\hline & \\
\hline $.005 \%, \mathrm{wt} / \mathrm{vo}$ & - \\
\hline 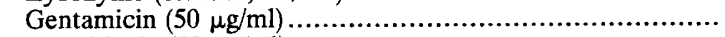 & - \\
\hline 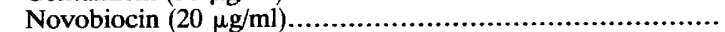 & - \\
\hline $\mathrm{n}(20 \mu \mathrm{g} / \mathrm{ml})$ & - \\
\hline 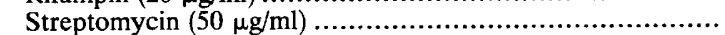 & - \\
\hline Vancomycin $(50 \mu \mathrm{g} / \mathrm{ml})$.. & - \\
\hline
\end{tabular}

${ }^{a}$ The data are based on the reactions of our eight isolates. In addition, $H$. cretacea tolerates $\mathrm{NaCl}$ concentrations of $<3 \%$ and grows at temperatures ranging from 13 to $37^{\circ} \mathrm{C}$.

${ }_{+}+$, positive; \pm , doubtful; -, negative; $v$, variable; NG, no growth. tics, Inc., Setauket, N.Y.), and the results are presented below as a dendrogram drawn by using unweighted pairgroup arithmetic average clustering (38). Methyl esters of cellular mycolic acids were prepared and detected as described by Tomiyasu (44). Isoprenoid quinones were extracted by the method of Collins et al. (5) and were analyzed by using a high-performance liquid chromatograph (HPLC) (model LC-6A; Shimadzu Corp.) (42) and a mass spectrometer (model QP-1000). The HPLC was equipped with a Cosmosil $5 \mathrm{C}_{18}$ column ( 4.6 by $150 \mathrm{~mm}$; Nacalai Tesque, Inc., Kyoto, Japan), and the elution solvent was a mixture of methanol and 2-propanol $(2: 1, \mathrm{vol} / \mathrm{vol})$. The positions of hydrogenation of $\mathrm{MK}-10\left(\mathrm{H}_{4}\right)$ obtained from the isolates were determined with a linked scan-fast atom bombardment mass spectrometer (model JMS SX102; JEOL, Ltd.).

Preparation and sequence analysis of 5S rRNAs. 5S rRNAs were prepared as described by Park et al. (33). The nucleotide sequence was determined by both chemical (35) and enzymatic (7) methods. Both terminal bases at the $3^{\prime}$ and $5^{\prime}$ ends were determined by thin-layer chromatography as described by Dekio et al. (6). The sequence alignment was based on the secondary structures constructed by the method described by Hori and Osawa (16). Evolutionary distances were represented by the $K_{\text {nuc }}$ value of Kimura (22), and a phylogenetic tree was constructed by the neighbor-joining method of Saitou and Nei (37).

Preparation of DNA, DNA base composition, and DNADNA hybridization. DNA was isolated from cells grown in yeast extract-glucose broth by using the method of Saito and Miura (36). The guanine-plus-cytosine $(\mathrm{G}+\mathrm{C})$ content of the DNA was determined by the HPLC method (20, 43). An equimolar mixture of nucleotides for analysis of DNA base composition (Yamasa Shoyu Co., Ltd., Choshi, Japan) was used for calculation of $\mathrm{G}+\mathrm{C}$ content. DNA-DNA relatedness was measured fluorometrically by using the microplate hybridization method described by Ezaki et al. (8).

Nucleotide sequence accession numbers. The new nucleotide sequence data reported in this paper appear in the DDBJ, EMBL, and GenBank nucleotide sequence data bases under the following accession numbers: Actinomadura madurae JCM 7436 ${ }^{\mathrm{T}}$, D13615; Microtetraspora glauca JCM $3300^{\mathrm{T}}$, D13616; $N$. dassonvillei JCM 7437 ${ }^{\mathrm{t}}$, D13617; Planobispora longispora JCM 3092 ${ }^{\mathrm{T}}$, D13618; Saccharothrix australiensis JCM $3370^{\mathrm{T}}$, D13619; Streptosporangium roseum JCM $3005^{\mathrm{T}}$, D13620; Streptosporangium viridogriseum JCM $3282^{\mathrm{T}}$, D13621; and Herbidospora cretacea $\mathrm{K}-319^{\mathrm{T}}$ (= JCM $\left.8553^{\mathrm{T}}\right), \mathrm{D} 13622$.

\section{RESULTS}

Morphology. All of the isolates produced well-developed, branched, non-fragmented substrate mycelia. Macroscopically, they formed apparent aerial masses on some media, but no distinct aerial hyphae were observed with light and scanning electron microscopes (Fig. 1 and 2). Straight, relatively short chains of nonmotile spores (10 to 30 spores per chain) were borne on the tips of sporophores branching from the vegetative hyphae. In an old culture incubated for more than 3 weeks, the tips of the spore chains were often entangled, resulting in globular forms. Each spore was oval, and its surface was smooth. No sporangia were observed.

Cultural, physiological, and biochemical characteristics. Cultural characteristics of our isolates are shown in Table 2. 


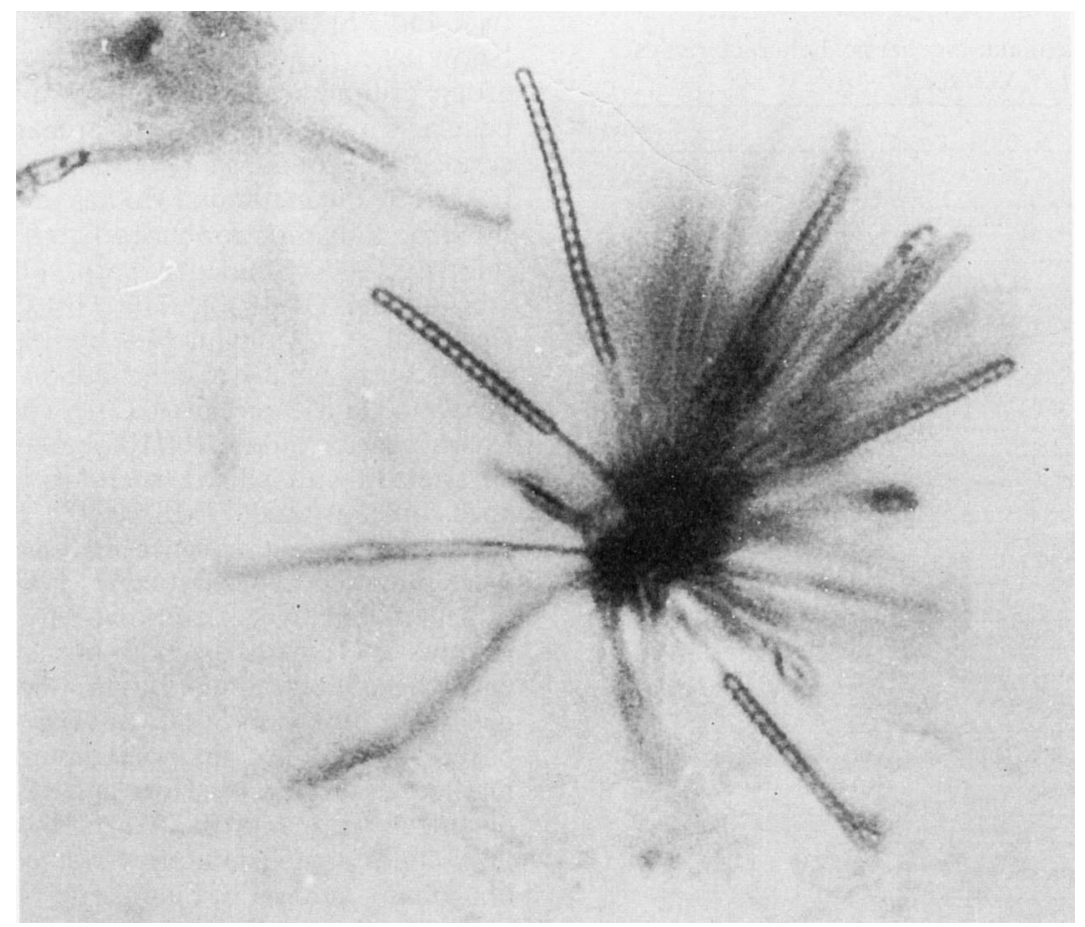

FIG. 1. Light micrograph of $H$. cretacea SF2625 grown on oatmeal agar (ISP medium 3) for 14 days at $28^{\circ} \mathrm{C}$.

All isolates except strain SF2742 had similar characteristics. Generally, the vegetative mycelium was colorless to yellowish brown, and no distinct pigments were produced. When sporulation occurred, the surface of the colony was white.
No diffusible pigments were produced in any agar medium, and growth on defined media did not occur or was very poor. The strain SF2742 colony surface became brownish yellow on some media.
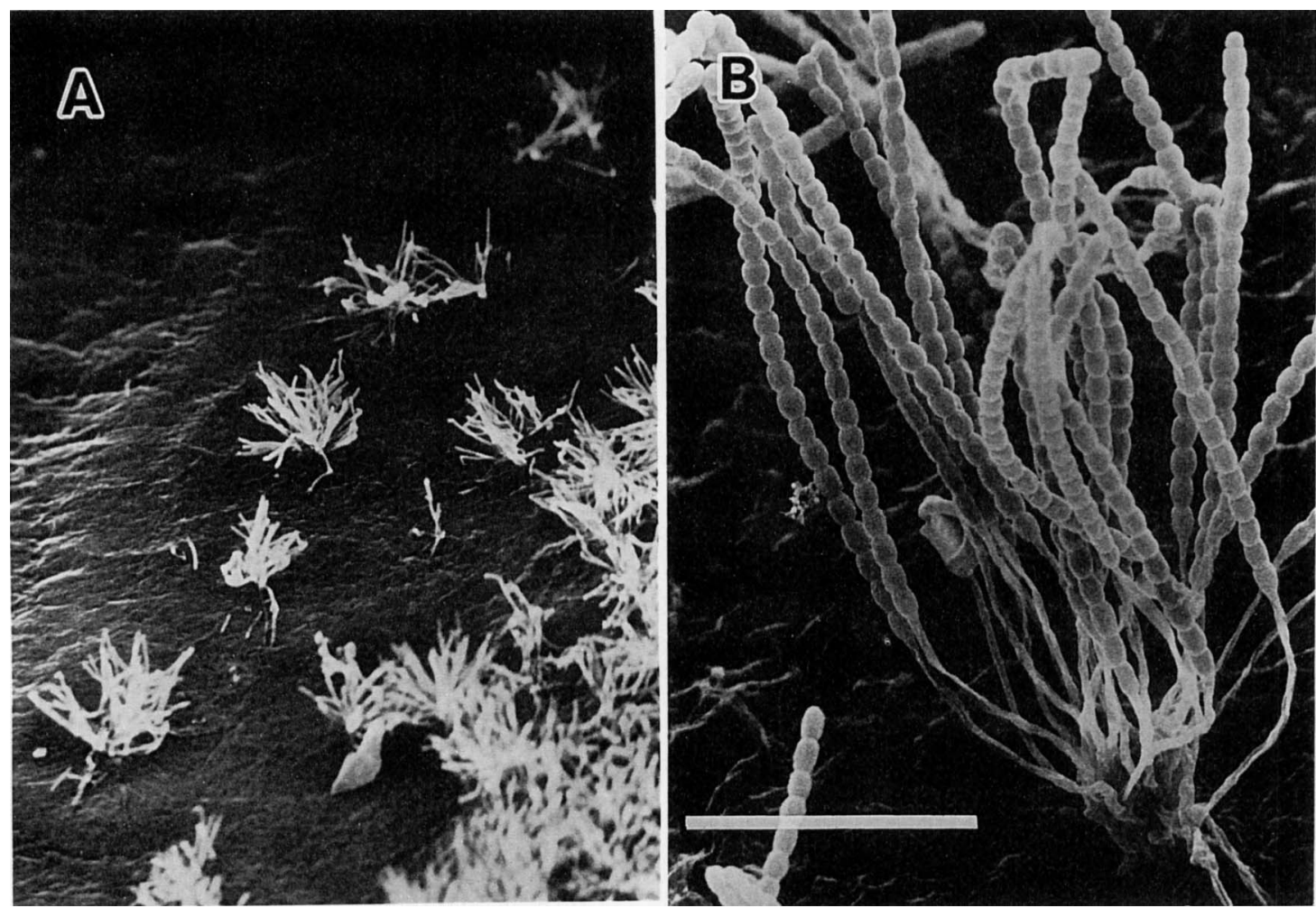

FIG. 2. Scanning electron micrographs of $H$. cretacea SF2625 grown on oatmeal agar (ISP medium 3 ) for 14 days at $28^{\circ} \mathrm{C} .(\mathrm{B}) \mathrm{Bar}=10 \mu \mathrm{m}$. 


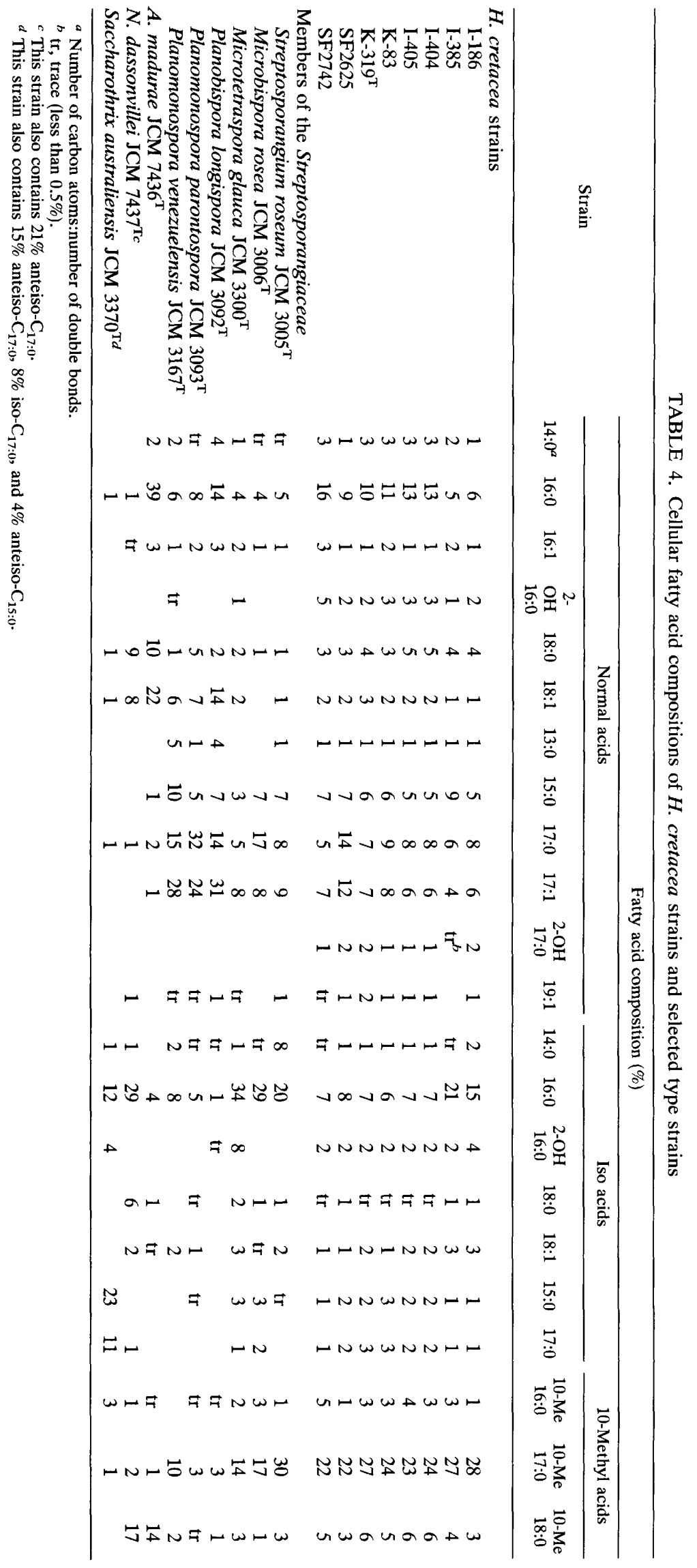




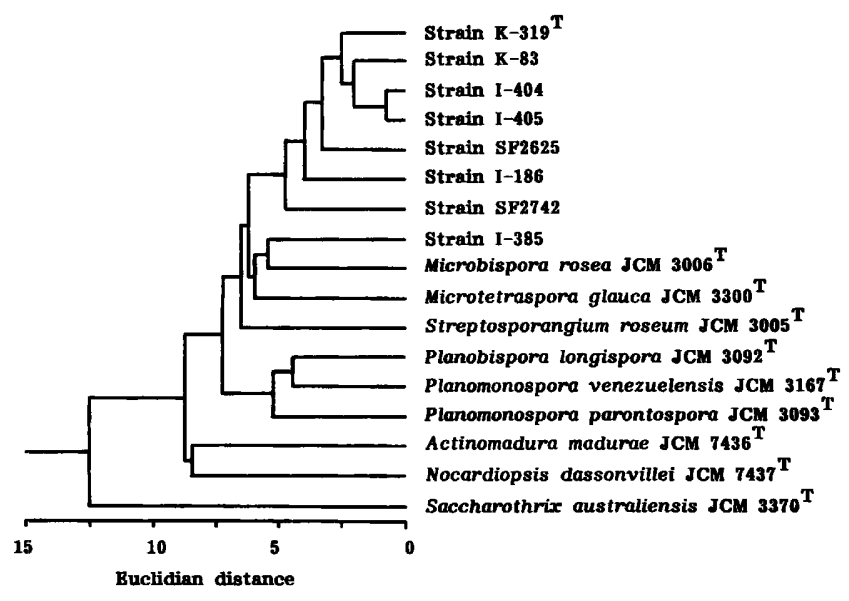

FIG. 3. Dendrogram showing relationships among strains of $H$. cretacea and related organisms based on fatty acid compositions (Table 5). Data were analyzed by using the NTSYS-pc program package, and clustering was performed by using unweighted pairgroup arithmetic average analysis.

All of the isolates also resembled each other in physiological and biochemical characteristics (Table 3).

Cell chemistry. The isolates were homogeneous in their chemotaxonomic properties. The molar ratio of glutamic acid to alanine to diaminopimelic acid to glycine in the hydrolysates of the purified cell walls was 1.00:1.46:0.99: 0.14 (calculated by defining the amount of glutamic acid as 1.00). The isomer of diaminopimelic acid was the meso isomer. As the amount of glycine was not sufficient to determine the cell wall type of Lechevalier and Lechevalier (28), we concluded that the cell wall type was type III. The acyl type of muramic acid in the cell walls was determined to be the acetyl type. Glucose, mannose, ribose, and a trace amount of madurose (3- $O$-methyl-D-galactose) were detected as whole-cell sugars, but galactose, arabinose, xylose, and rhamnose were absent (whole-cell sugar pattern B of Lechevalier and Lechevalier [28]).

The polar lipid profile was characterized by the presence of phosphatidylethanolamine and its derivatives and ninhydrin-positive glycophospholipids. This result suggests that the phospholipid pattern of the isolates is the type PIV pattern of Lechevalier et al. (27). The cellular fatty acid compositions of the isolates and of some type strains used for comparison are shown in Table 4 . The fatty acids of the isolates consisted of straight, iso-branched, 10-methyl, and 2-hydroxyl acids, and the members of the family Streptosporangiaceae tested had a similar pattern (type $3 \mathrm{c}$ of Kroppenstedt [23]). The results of a cluster analysis based on fatty acid compositions are shown in Fig. 3. Mycolic acids were not detected in the cells of the isolates. The predominant menaquinone was MK-10 $\left(\mathrm{H}_{4}\right)$; small amounts of MK-10 $\left(\mathrm{H}_{6}\right)$, MK-10 $\left(\mathrm{H}_{2}\right)$, MK-10 $\left(\mathrm{H}_{0}\right)$, and MK-9 $\left(\mathrm{H}_{4}\right)$ were also present (Table 5). The retention time of the MK-10 $\left(\mathrm{H}_{4}\right)$ molecule obtained from the isolates in the HPLC analysis was manifestly different from that of the previously known MK$10\left(\mathrm{H}_{4}\right)$ molecule, and this fact suggested that these two MK-10 $\left(\mathrm{H}_{4}\right)$ molecules were isomeric. Figure 4 shows the linked scan mass spectrum of $\mathrm{MK}-10\left(\mathrm{H}_{4}\right)$ prepared from strain $\mathrm{K}-319^{\mathrm{T}}$, and the fragment ion peaks of this spectrum indicate that the molecule is saturated at the sites of units III and IX [MK-10(III,IX- $\left.\left.\mathrm{H}_{4}\right)\right]$. These positions of hydrogenation have not been reported previously. The $\mathrm{G}+\mathrm{C}$ contents of our isolates were 69 to $71 \mathrm{~mol} \%$ (Table 6).

5S rRNA sequence. The nucleotide sequences of the $5 \mathrm{~S}$ rRNAs from one of our isolates (strain $\mathrm{K}-319^{\mathrm{T}}$ ) and some authentic type strains are shown in Fig. 5. The sequence of Streptomyces griseus was taken from the data of Park et al. (34). Figure 6 shows an unrooted phylogenetic tree based on the sequence data, which indicates that the 5S rRNA sequence of strain $\mathrm{K}-319^{\mathrm{T}}$ is very similar to the $5 \mathrm{~S}$ rRNA sequences of members of the family Streptosporangiaceae, particularly Streptosporangium roseum and Planobispora longispora. The phylogenetic tree also indicates that

TABLE 5. Menaquinone compositions of $H$. cretacea strains and selected type strains

\begin{tabular}{|c|c|c|c|c|c|c|c|c|c|c|c|}
\hline \multirow{2}{*}{ Strain } & \multicolumn{11}{|c|}{ Menaquinone composition (\%) } \\
\hline & $\begin{array}{c}\text { MK-9 } \\
\left(\mathrm{H}_{0}\right)\end{array}$ & $\begin{array}{c}\mathrm{MK}-9 \\
\left(\mathrm{H}_{2}\right)\end{array}$ & $\begin{array}{c}\text { MK-9 } \\
(\text { II,III-H })_{4}^{a}\end{array}$ & $\begin{array}{c}\text { MK-9 } \\
\left(\mathrm{III}, \mathrm{VIII}-\mathrm{H}_{4}\right)^{a}\end{array}$ & $\begin{array}{c}\text { MK-9 } \\
\left(\mathbf{H}_{6}\right)\end{array}$ & $\begin{array}{c}\text { MK-9 } \\
\left(\mathbf{H}_{8}\right)\end{array}$ & $\begin{array}{c}\mathrm{MK}-10 \\
\left(\mathbf{H}_{0}\right)\end{array}$ & $\begin{array}{c}\mathrm{MK}-10 \\
\left(\mathrm{H}_{2}\right)\end{array}$ & $\begin{array}{c}\text { MK-10 } \\
\left(\mathrm{II}, \mathrm{III}-\mathrm{H}_{4}\right)^{a}\end{array}$ & $\begin{array}{c}\text { MK-10 } \\
\left(\text { III, }, \text { IX-H }-H_{4}\right)^{b}\end{array}$ & $\underset{\left(\mathrm{H}_{6}\right)}{\mathrm{MK}-10}$ \\
\hline \multicolumn{12}{|l|}{ H. cretacea strains } \\
\hline I-186 & & & & 5 & $\operatorname{tr}^{c}$ & & 4 & 12 & & 72 & 7 \\
\hline $\mathrm{I}-385$ & & & & 4 & $\operatorname{tr}$ & & 5 & 11 & & 69 & 10 \\
\hline I-404 & & & & 7 & 1 & & 3 & 9 & & 67 & 12 \\
\hline $\mathrm{I}-405$ & & & & 7 & 1 & & 3 & 10 & & 66 & 11 \\
\hline $\mathrm{K}-319^{\mathrm{T}}$ & & & & 6 & 1 & & 2 & 7 & & 67 & 17 \\
\hline $\mathrm{K}-83$ & & & & 6 & 1 & & 4 & 12 & & 65 & 12 \\
\hline SF2625 & & & & 3 & & & 2 & 12 & & 74 & 8 \\
\hline SF2742 & & & & 4 & & & 6 & 12 & & 71 & 6 \\
\hline \multicolumn{12}{|l|}{ Members of the Streptosporangiaceae } \\
\hline Microbispora rosea JCM $3006^{\mathrm{T}}$ & 7 & 44 & & 41 & 3 & 1 & & 2 & & & \\
\hline Microtetraspora glauca $\mathrm{JCM} 3300^{\mathrm{T}}$ & 16 & 18 & & 57 & 6 & $\operatorname{tr}$ & & & & & \\
\hline Planobispora longispora $\mathrm{JCM} 3092^{\mathrm{T}}$ & 5 & 55 & & 31 & 4 & $\operatorname{tr}$ & & & & & \\
\hline Planomonospora parontospora JCM $3093^{\mathrm{T}}$ & 10 & 74 & & 10 & $\operatorname{tr}$ & & & & & & \\
\hline Planomonospora venezuelensis $\mathrm{JCM} 3167^{\mathrm{T}}$ & 9 & 55 & & 30 & 2 & & & & & & \\
\hline Streptosporangium roseum JCM $3005^{\mathrm{T}}$ & 2 & 42 & & 48 & 7 & $\operatorname{tr}$ & & & & & \\
\hline A. madurae JCM $7436^{\mathrm{T}}$ & & & 6 & & 73 & 20 & & & & & \\
\hline N. dassonvillei JCM $7437^{\mathrm{T}}$ & 3 & 3 & & & & & 26 & 30 & 23 & & 6 \\
\hline Saccharothrix australiensis JCM $3370^{\text {T }}$ & 3 & 3 & 56 & & & & & 2 & 28 & & \\
\hline
\end{tabular}

a Positions of hydrogenation were determined by comparing retention times with retention times of previously described structures.

${ }^{b}$ Positions of hydrogenation were determined by mass spectrometry by the linked scan method (Fig. 3 ).

$c$ tr, trace (less than 1\%). 

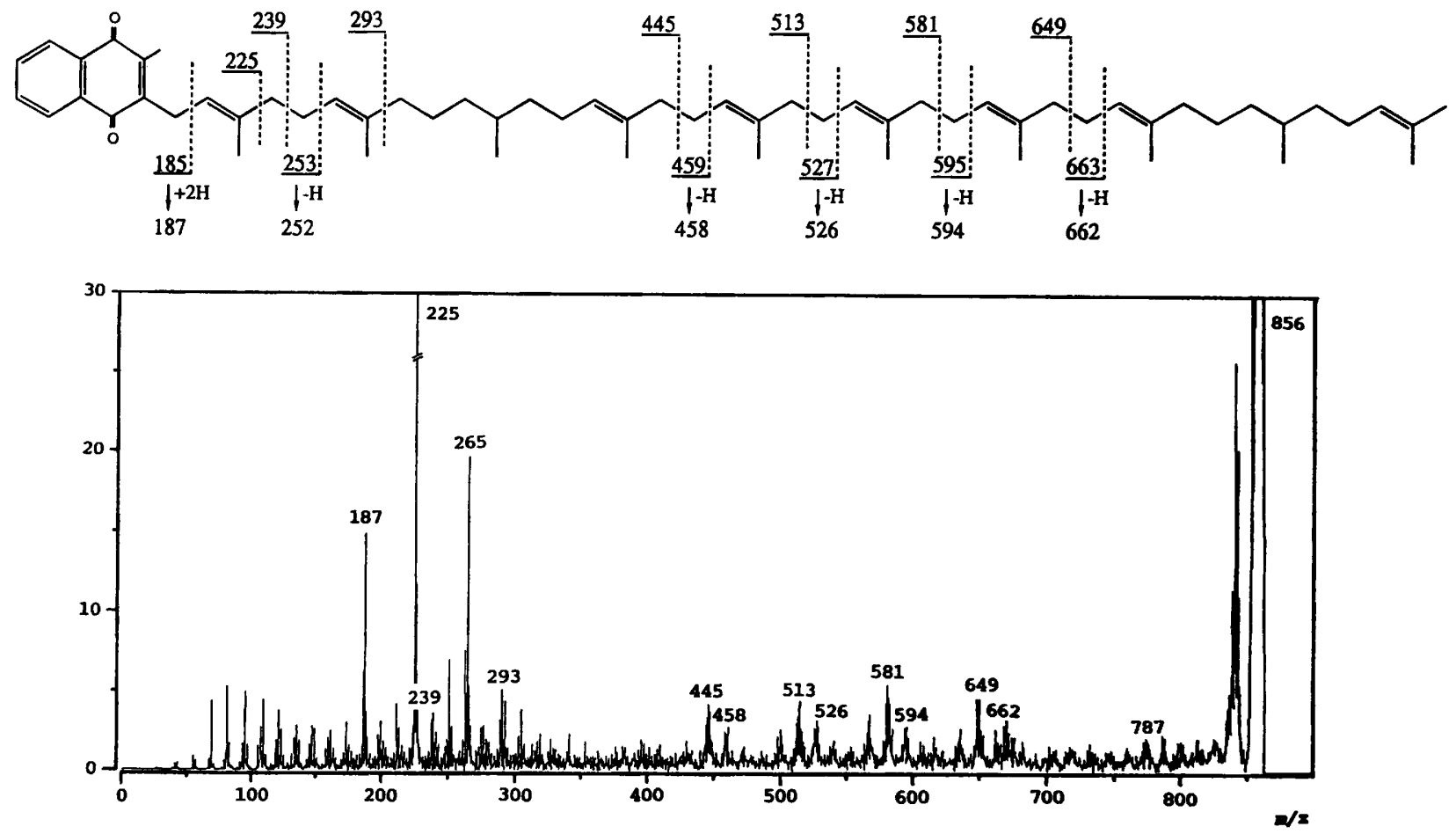

FIG. 4. Linked scan-fast atom bombardment mass spectrum of $\mathrm{MK}-10\left(\mathrm{H}_{4}\right)$ obtained from $\mathrm{H}$. cretacea $\mathrm{K}-319^{\mathrm{T}}\left(=\mathrm{JCM} 8553^{\mathrm{T}}\right)$ and assignment of the fragment peaks.

Streptosporangium viridogriseum is located apart from the other members of the family.

DNA-DNA hybridization. The levels of DNA relatedness are shown in Table 6 . There were three homology groups defined at a level of more than $70 \%$ among our isolates. The first group contained strains I-186, I-404, I-405, K-83, and $\mathrm{K}-319^{\mathrm{T}}$. The second group consisted of strains $\mathrm{I}-385$ and SF2742, and the third group was a single-member group containing strain SF2625. However, the levels of relatedness among these three groups were relatively high, ranging from 44 to $68 \%$.

\section{DISCUSSION}

The family Streptosporangiaceae is a taxon mainly defined by chemotaxonomy, and our isolates shared chemotaxonomic characteristics with members of this family in many ways (Table 7), including a type III cell wall composition, $N$-acetylated muramic acid in the cell walls, and a type PIV phospholipid composition. Fatty acid type 3c, characterized by iso-hexadecanoic, $n$-heptadecenoic, 10 methyl heptadecanoic, and 2-hydroxy acids (24), is also the fatty acid type. The dendrogram based on the quantitative fatty acid analyses (Fig. 3) shows that the isolates and the members of the family are not clearly separated by this cluster analysis, while they are distinguished from other strains having cell wall type III which are not in the family Streptosporangiaceae (A. madurae, $N$. dassonvillei, and Saccharothrix australiensis strains). On the other hand, our isolates have a novel menaquinone, MK-10(III,IX-H ${ }_{4}$ ), which is different from the menaquinone of the previously described members of the family Streptosporangiaceae. The previously described members of this family have MK9(III,VIII- $\mathrm{H}_{4}$ ) exclusively as their tetrahydrogenated

TABLE 6. DNA base compositions and levels of DNA relatedness among $H$. cretacea strains

\begin{tabular}{|c|c|c|c|c|c|c|c|c|c|c|}
\hline \multirow{2}{*}{ Strain } & \multirow{2}{*}{$\begin{array}{c}\mathrm{G}+\mathrm{C} \text { content } \\
\quad(\mathrm{mol} \%)\end{array}$} & \multicolumn{9}{|c|}{$\%$ of DNA complementarity with labeled DNA from: } \\
\hline & & $\mathrm{K}-319^{\mathrm{T}}$ & I-186 & I-404 & $\mathrm{I}-405$ & K-83 & I-385 & SF2742 & SF2625 & $\mathrm{JCM} 3005^{\mathrm{T}}$ \\
\hline \multicolumn{11}{|l|}{ H. cretacea strains } \\
\hline $\mathrm{K}-319^{\mathrm{T}}$ & 70 & 100 & 102 & 89 & 80 & 100 & 57 & 69 & 57 & 26 \\
\hline $\mathrm{I}-186$ & 70 & 84 & 100 & 93 & 88 & 82 & 61 & 65 & 53 & 26 \\
\hline I-404 & 70 & 82 & 87 & 100 & 96 & 91 & 61 & 62 & 54 & 25 \\
\hline I-405 & 70 & 77 & 90 & 104 & 100 & 83 & 60 & 64 & 51 & 26 \\
\hline K-83 & 70 & 88 & 94 & 88 & 87 & 100 & 65 & 68 & 57 & 27 \\
\hline I-385 & 71 & 54 & 64 & 64 & 68 & 56 & 100 & 81 & 58 & 29 \\
\hline SF2742 & 70 & 44 & 62 & 56 & 63 & 45 & 70 & 100 & 44 & 20 \\
\hline SF2625 & 69 & 49 & 68 & 68 & 64 & 58 & 57 & 66 & 100 & 26 \\
\hline $\begin{array}{l}\text { Streptosporangium roseum JCM } \\
3005^{\mathrm{T}}\end{array}$ & 70 & 14 & 22 & 25 & 27 & 15 & 20 & 21 & 18 & 100 \\
\hline
\end{tabular}



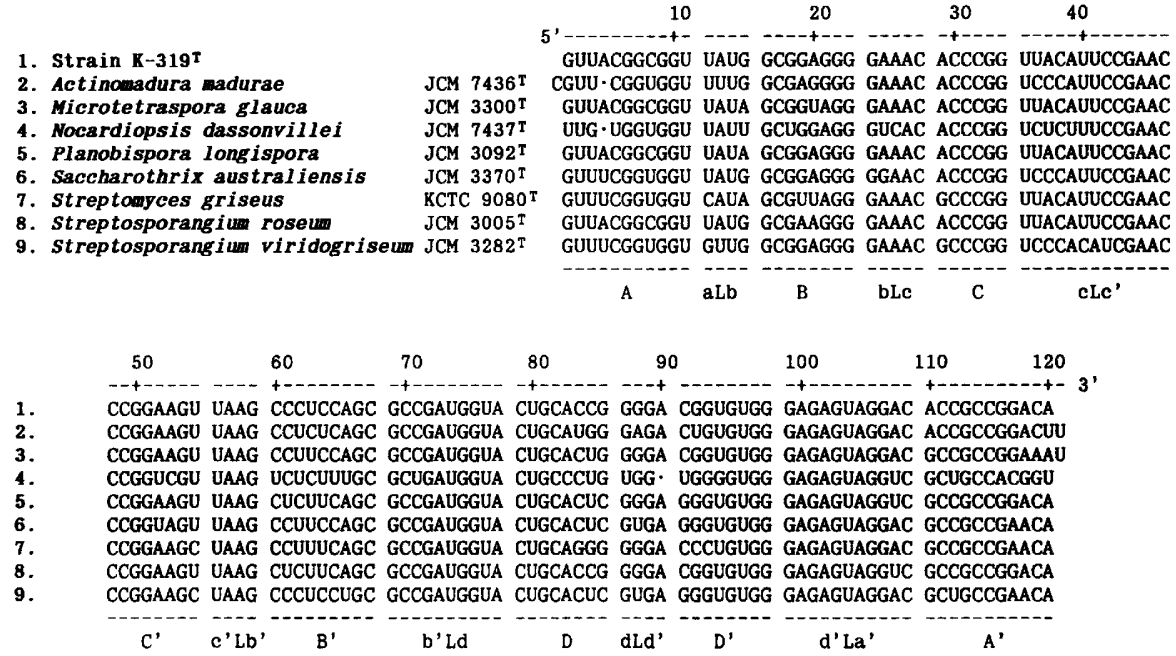

FIG. 5. Nucleotide sequence alignment of $5 \mathrm{~S}$ rRNAs obtained from $H$. cretacea $\mathrm{K}-319^{\mathrm{T}}$ and some selected type strains. The data for Streptomyces griseus KCTC $9080^{\mathrm{T}}$ were obtained from reference 34 . The names of regions are the names assigned by Hori and Osawa (16).

menaquinone $(4,25)$, whereas it is known that the position of tetrahydrogenation in gram-positive bacteria generally occurs at the sites of units II and III $(3,4,17,46)$. Although there is a difference in the length of the side chain between the previously described members of the family Streptosporangiaceae and our isolates, the saturation of tetrahydrogenated menaquinones occurs in the same fashion, so that the third isoprene unit from the 2-methyl-1,4-naphthoquinone moiety and the second isoprene unit from the $\omega$ terminus are saturated. This fact, as well as the agreement in other chemotaxonomic characteristics, indicates that our isolates do belong to the family Streptosporangiaceae. This assignment is supported by the results of the phylogenetic analysis performed with 5S rRNA sequences (Fig. 6). The phylogenetic position of one of the isolates (strain $\mathrm{K}-319^{\mathrm{T}}$ ) is close to that of Streptosporangium roseum and Planobispora longispora.

At present, morphology is the sole criterion used to distinguish genera in the family Streptosporangiaceae (Table 7). The morphological features of our isolates are somewhat similar to those of members of the genus Microtetraspora as emended by Kroppenstedt et al. (25) with respect to the formation of spore chains and the absence of sporangia. However, our isolates differ from all previously described genera by the absence of aerial hyphae and the position of sporophore formation. In addition to the morphological differences, our isolates form a single group which can be separated from other genera by a chemotaxonomic feature, the number of isoprene units of the menaquinone (Table 7).
Therefore, we propose a new genus, Herbidospora, for our strains.

Taxonomic consideration at the species level in the genus Herbidospora was based on cultural, physiological, and biochemical properties and levels of DNA-DNA relatedness. When cultural characteristics were examined (Table 2), strain SF2742 was the only isolate exhibiting a yellow colony surface. However, a high level of DNA relatedness (Table 6) was found between strain SF2742 and strain I-385 (more than $70 \%$ ), and this result indicates that color formation is not significant for classification at the species level. Furthermore, all of our isolates exhibited similar physiological and biochemical characteristics, and it is therefore difficult to discriminate strain SF2742 from the other isolates by colony coloration alone. The DNA-DNA hybridization experiment indicated that the isolates fell into three homology groups, with the levels of DNA-DNA relatedness among these groups ranging from 44 to $68 \%$. These values suggest that the strains represent three subspecies (19). However, we placed all of the isolates into a single taxon, $H$. cretacea sp. nov., because clearly differential characteristics were lacking.

The new genus and species which we propose are described below; an emended description of the family Streptosporangiaceae is also given below.

Emended description of the family Streptosporangiaceae Goodfellow, Stanton, Simpson, and Minnikin 1990. The emended description below is similar to the original description (13) except for morphological characteristics and menaquinone composition.

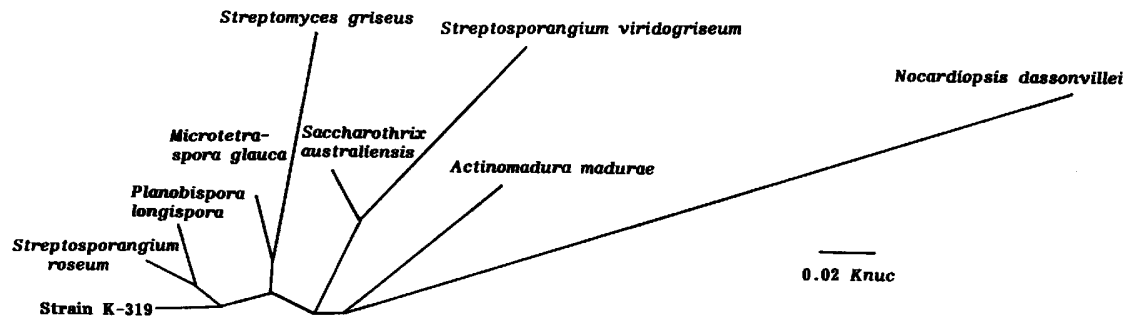

FIG. 6. Phylogenetic relationships between $H$. cretacea $\mathrm{K}-319^{\mathrm{T}}$ and some selected type strains. 
TABLE 7. Comparison of the genus Herbidospora with related genera of actinomycetes having type III cell walls

\begin{tabular}{|c|c|c|c|c|c|c|c|}
\hline \multirow[b]{2}{*}{ Genus } & \multicolumn{3}{|c|}{ Morphology } & \multicolumn{4}{|c|}{ Chemotaxonomy } \\
\hline & $\begin{array}{c}\text { Aerial } \\
\text { mycelium }\end{array}$ & Sporangium & $\begin{array}{l}\text { Motile } \\
\text { spores }\end{array}$ & $\begin{array}{c}\text { Whole-cell } \\
\text { sugar } \\
\text { pattern }\end{array}$ & $\begin{array}{l}\text { Phospholipid } \\
\text { type }\end{array}$ & $\begin{array}{l}\text { Fatty acid } \\
\text { type }\end{array}$ & Predominant menaquinones \\
\hline Herbidospora & - & - & - & B & PIV & $3 c$ & $\begin{array}{l}\left.\left.\text { MK-10(III,IX-H } \mathrm{H}_{4}\right), \text { MK-10( } \mathrm{H}_{6}\right), \\
\left.\text { MK-10( } \mathrm{H}_{2}\right)\end{array}$ \\
\hline $\begin{array}{l}\text { Members of the Streptosporangiaceae } \\
\text { Microbispora }\end{array}$ & + & - & - & B & PIV & $3 c$ & 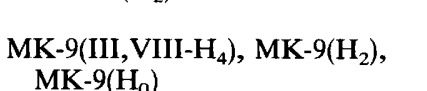 \\
\hline Microtetraspora & + & - & - & $\mathrm{B}$ or $\mathrm{C}$ & PIV & $3 c$ & 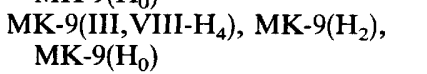 \\
\hline Planobispora & + & + & + & B & PIV & $3 c$ & $\begin{array}{l}\left.\left.\text { MK-9(III,VIII-H }{ }_{4}\right), \text { MK-9( } \mathrm{H}_{2}\right) \text {, } \\
\text { MK-9 }\left(\mathrm{H}_{0}\right)\end{array}$ \\
\hline Planomonospora & + & + & + & $\mathrm{B}$ & PIV & $3 c$ & 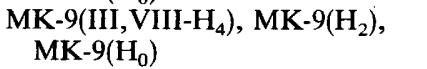 \\
\hline Streptosporangium & + & + & - & B & PIV & $3 c$ & $\begin{array}{l}\left.\text { MK-9(III,VIII-H }{ }_{4}\right), \text { MK-9 }\left(\mathrm{H}_{2}\right) \text {, } \\
\text { MK-9 }\left(\mathrm{H}_{0}\right)\end{array}$ \\
\hline Actinomadura & + & - & - & B & PI & $3 a$ & $\begin{array}{l}\left.\text { MK-9(II,III,VIII-H }{ }_{6}\right) \text {, MK- } \\
\left.\text { 9(II,III,VIII,IX-H }{ }_{8}\right)\end{array}$ \\
\hline Nocardiopsis & + & - & - & $\mathrm{C}$ & PIII & $3 d$ & MK-10(II-H $),$ MK-10(II,III-H $\left.{ }_{4}\right)$ \\
\hline Saccharothrix & + & - & - & C & PII & $3 \mathrm{f}$ & MK-9(II,III-H 4$)$, MK-10(II,III-H \\
\hline Spirillospora & + & + & + & B & PI or PII & $3 a$ & 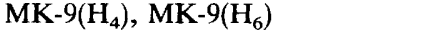 \\
\hline
\end{tabular}

Aerobic, gram-positive, non-acid-fast actinomycetes that form stable substrate mycelia. Aerial mycelia are variable. When aerial hyphae are formed, spores or sporangia are borne on sporophores derived from aerial hyphae. When aerial hyphae are not formed, the sporophores are derived from vegetative mycelia. Spores are nonmotile or motile.

Cell walls contain meso-diaminopimelic acid and $\mathrm{N}$-acetylated muramic acid, but lack a significant amount of glycine (cell wall type III). The peptidoglycan type is type $\mathrm{Al} \gamma$. Madurose in whole cells is variable (whole-cell sugar pattern B or C). Glucosamine-containing phospholipids are present as diagnostic polar lipids (phospholipid type PIV). The cellular fatty acids include straight, iso- and anteisobranched, and 10-methyl acids. The major proportion of the unsaturated, di- and tetrahydrogenated menaquinones have 9 or 10 isoprene units. Saturation of the tetrahydrogenated menaquinones occurs at the sites of unit III and the second unit from the $\omega$ terminus [MK-9(III,VIII- $H_{4}$ ) or MK-10(III, IX- $\left.\left.\mathrm{H}_{4}\right)\right]$. Mycolic acids are absent. The $\mathrm{G}+\mathrm{C}$ content of the DNA ranges from 66 to $74 \mathrm{~mol} \%$.

Description of Herbidospora gen. nov. Herbidospora (Her. bi.do.spo'ra. L. adj. herbidus, grassy; Gr. n. spora, a seed; M.L. f. n. Herbidospora, organism forming spores like grass). Nonfragmented branched vegetative hyphae are formed, but true aerial hyphae are not formed. Short chains of spores (10 to 30 spores per chain) are borne at the tips of sporophores, which are derived from the vegetative mycelia in clusters. Spores are nonmotile.

Cell walls contain meso-diaminopimelic acid and $N$-acetylated muramic acid, but lack a significant amount of glycine (cell wall type III). Whole-cell hydrolysates contain a trace amount of madurose. Contains phosphatidylethanolamine and its derivatives and glucosamine-containing phospholipids (phospholipid type PIV). The cellular fatty acid composition is characterized by iso-hexadecanoic, $n$-hexadecanoic, $n$-heptadecenoic, 10-methyl heptadecanoic, and 2-hydroxy acids (fatty acid type $3 \mathrm{c}$ ). The predominant isoprenoid quinone is a tetrahydrogenated menaquinone with 10 isoprene units, and the hydrogenation occurs at units III and IX [MK-10(III,IX-H $\left.)_{4}\right)$. MK-10 $\left(\mathrm{H}_{2}\right)$, MK-10 $\left(\mathrm{H}_{0}\right)$, MK-10 $\left(\mathrm{H}_{6}\right)$, and MK-9(III,VIII- $\mathrm{H}_{4}$ ) are also present as minor components. The type species is $H$. cretacea.

Description of Herbidospora cretacea sp. nov. Herbidospora cretacea (cre.ta'ce.a. L. fem. adj. cretacea, chalk white). Vegetative mycelia are yellow to brown on most media. When sporulation occurs, the surface of the colony is white or brownish yellow. A diffusible pigment is not produced. Decomposes casein, DNA, esculin, hypoxanthine, and starch, but not adenine, arbutin, guanine, keratin, tyrosine, and xanthine. Utilizes L-arabinose, cellobiose, D-fructose, D-galactose, D-glucose, maltose, D-mannitol, D-mannose, D-ribose, starch, sucrose, and D-xylose as sole carbon sources, but not adonitol, cellulose, dulcitol, $i$-erythritol, glycerol, myo-inositol, melezitose, and raffinose. Utilizes fumaric acid, DL-lactic acid, L-malic acid, and succinic acid, but not benzoic acid, citric acid, mucic acid, oxalic acid, propionic acid, and L-tartaric acid. No growth occurs in the presence of $3 \% \mathrm{NaCl}$. Susceptible to lysozyme, gentamicin, novobiocin, rifampin, streptomycin, and vancomycin. Requires thiamine for growth. Mesophilic. The $\mathrm{G}+\mathrm{C}$ content of the DNA is 69 to $71 \mathrm{~mol} \%$. The type strain is strain K-319 (= JCM 8553).

\section{ACKNOWLEDGMENTS}

We thank M. Uramoto, The Institute of Physical and Chemical Research (RIKEN), Wako, Saitama, Japan and A. Kusai, JEOL, Ltd., Tokyo, Japan, for determining positions of hydrogenation in the menaquinone. We also thank S. Amano, Meiji Seika Kaisha, Ltd., Yokohama, Kanagawa, Japan, for obtaining the light and scanning electron micrographs.

\section{REFERENCES}

1. Athalye, M., M. Goodfellow, and D. E. Minnikin. 1984. Menaquinone composition in the classification of Actinomadura and related taxa. J. Gen. Microbiol. 130:817-823.

2. Collins, M. D., M. Faulkner, and M. Keddie. 1984. Menaquinone composition of some sporeforming actinomycetes. Syst. Appl. Microbiol. 5:20-29.

3. Collins, M. D., and R. M. Kroppenstedt. 1987. Structures of the partially saturated menaquinones of Glycomyces rutgersensis. FEMS Microbiol. Lett. 44:215-219. 
4. Collins, M. D., R. M. Kroppenstedt, J. Tamaoka, K. Komagata, and T. Kinoshita. 1988. Structures of tetrahydrogenated menaquinones from Actinomadura angiospora, Faenia rectivirgula, and Saccharothrix australiensis. Curr. Microbiol. 17:275-279.

5. Collins, M. D., T. Pirouz, M. Goodfellow, and D. E. Minnikin. 1977. Distribution of menaquinones in actinomycetes and corynebacteria. J. Gen. Microbiol. 100:221-230.

6. Dekio, S., R. Yamasaki, J. Jidoi, H. Hori, and S. Osawa. 1984. Secondary structure and phylogeny of Staphylococcus and Micrococcus 5S rRNAs. J. Bacteriol. 159:233-237.

7. Donis-Keller, H. 1980. Phy M: an RNase activity specific for U and $A$ residues useful in RNA sequence analysis. Nucleic Acids Res. 8:3133-3142.

8. Ezaki, T., Y. Hashimoto, and E. Yabuuchi. 1989. Fluorometric deoxyribonucleic acid-deoxyribonucleic acid hybridization in microdilution wells as an alternative to membrane filter hybridization in which radioisotopes are used to determine genetic relatedness among bacterial strains. Int. J. Syst. Bacteriol. 39:224-229.

9. Fowler, V. J., W. Ludwig, and E. Stackebrandt. 1985. Ribosomal ribonucleic acid cataloguing in bacterial systematics: the phylogeny of Actinomadura, p. 17-40. In M. Goodfellow and D. E. Minnikin (ed.), Chemical methods in bacterial systematics. Academic Press, Ltd., London.

10. Goodfellow, M. 1971. Numerical taxonomy of some nocardioform bacteria. J. Gen. Microbiol. 69:33-80.

11. Goodfellow, M. 1989. The actinomycetes. I. Suprageneric classification of actinomycetes, p. 2333-2339. In S. T. Williams, M. E. Sharpe, and J. G. Holt (ed.), Bergey's manual of systematic bacteriology, vol. 4. Williams \& Wilkins, Baltimore.

12. Goodfellow, M., and T. Cross. 1984. Classification, p. 7-164. In M. Goodfellow, M. Mordarski, and S. T. Williams (ed.), The biology of the actinomycetes. Academic Press, Inc. (London), Ltd., London.

13. Goodfellow, M., L. J. Stanton, K. E. Simpson, and D. E. Minnikin. 1990. Numerical and chemical classification of Actinoplanes and some related actinomycetes. J. Gen. Microbiol. 136:19-36.

14. Gordon, R. E., D. A. Barnett, J. E. Handerhan, and C. H.-N. Pang. 1974. Nocardia coeliaca, Nocardia autotrophica, and the nocardin strain. Int. J. Syst. Bacteriol. 24:54-63.

15. Hayakawa, M., and H. Nonomura. 1987. Humic acid-vitamin agar, a new medium for the selective isolation of soil actinomycetes. J. Ferment. Technol. 65:501-509.

16. Hori, H., and S. Osawa. 1979. Evolutionary change in 5S RNA secondary structure and a phylogenic tree of 54 5S RNA species. Proc. Natl. Acad. Sci. USA 76:381-385.

17. Howarth, O. W., E. Grund, R. M. Kroppenstedt, and M. D. Collins. 1986. Structural determination of a new naturally occurring cyclic vitamin K. Biochem. Biophys. Res. Commun. 140:916-923.

18. Jacobson, E., W. C. Grauville, and C. E. Fogs. 1958. Color harmony manual, 4th ed. Container Corporation of America, Chicago.

19. Johnson, J. L. 1984. Bacterial classification. III. Nucleic acids in bacterial classification, p. 8-11. In N. R. Krieg and J. G. Holt (ed.), Bergey's manual of systematic bacteriology, vol. 1. Williams \& Wilkins, Baltimore.

20. Kaneko, T., K. Katoh, M. Fujimoto, M. Kumagai, J. Tamaoka, and Y. Katayama-Fujimura. 1986. Determination of the nucleotide composition of a deoxyribonucleic acid by high-performance liquid chromatography of its enzymatic hydrolysate: a review. J. Microbiol. Methods 4:229-240.

21. Kawamoto, I., T. Oka, and T. Nara. 1981. Cell wall composition of Micromonospora olivoasterospora, Micromonospora sagamiensis, and related organisms. J. Bacteriol. 146:527-534.

22. Kimura, M. 1980 . A simple method for estimating evolutionary rates of base substitutions through comparative studies of nucleotide sequences. J. Mol. Evol. 16:111-120.

23. Kroppenstedt, R. M. 1985 . Fatty acid and menaquinone analysis of actinomycetes and related organisms, p. 173-199. In M. Goodfellow and D. E. Minnikin (ed.), Chemical methods in bacterial systematics. Academic Press, Ltd., London.

24. Kroppenstedt, R. M. 1992. The genus Nocardiopsis, p. 1139-
1156. In A. Balows, H. G. Trüper, M. Dworkin, W. Harder, and K.-H. Schleifer (ed.), The prokaryotes. Springer-Verlag New York, Inc., New York.

25. Kroppenstedt, R. M., E. Stackebrandt, and M. Goodfellow. 1990. Taxonomic revision of the actinomycete genera Actinomadura and Microtetraspora. Syst. Appl. Microbiol. 13:148-160.

26. Kudo, T., and A. Seino. 1987. Transfer of Streptosporangium indianense Gupta 1965 to the genus Streptomyces as Streptomyces indiaensis (Gupta 1965) comb. nov. Int. J. Syst. Bacteriol. 37:241-244.

27. Lechevalier, M. P., C. De Bievre, and H. Lechevalier. 1977. Chemotaxonomy of aerobic actinomycetes: phospholipid composition. Biochem. Syst. Ecol. 5:249-260.

28. Lechevalier, M. P., and H. Lechevalier. 1970. Chemical composition as a criterion in the classification of aerobic actinomycetes. Int. J. Syst. Bacteriol. 20:435-443.

29. Lechevalier, M. P., A. E. Stern, and H. A. Lechevalier. 1981. Phospholipids in the taxonomy of actinomycetes. Zentralbl. Bakteriol. Microbiol. Hyg. Abt. 1 Suppl. 11:111-116.

30. Meyertons, J. L., D. P. Labeda, G. L. Cote, and M. P. Lechevalier. 1988. A new thin-layer chromatographic method for whole-cell sugar analysis of Micromonospora species. Actinomycetes 20:182-192.

31. Minnikin, D. E., A. G. O'Donnell, M. Goodfellow, G. Alderson, M. Athalye, A. Schaal, and J. H. Parlett. 1984. An integrated procedure for the extraction of bacterial isoprenoid quinones and polar lipids. J. Microbiol. Methods 2:233-241.

32. Miyadoh, S., S. Amano, H. Tohyama, and T. Shomura. 1990. A taxonomic review of the genus Microbispora and a proposal to transfer two species to the genus Actinomadura and to combine ten species into Microbispora rosea. J. Gen. Microbiol. 136: 1905-1913.

33. Park, Y.-H., H. Hori, K.-I. Suzuki, S. Osawa, and K. Komagata. 1987. Phylogenetic analysis of the coryneform bacteria by $5 \mathrm{~S}$ rRNA sequences. J. Bacteriol. 169:1801-1806.

34. Park, Y.-H., D.-G. Yim, E. Kim, Y.-H. Kho, T.-I. Mheen, J. Lonsdale, and M. Goodfellow. 1991. Classification of acidophilic, neutrotolerant and neutrophilic streptomycetes by nucleotide sequencing of $5 \mathrm{~S}$ ribosomal RNA. J. Gen. Microbiol. 137:2265-2269.

35. Peattie, D. A. 1979. Direct chemical method for sequencing RNA. Proc. Natl. Acad. Sci. USA 76:1760-1764.

36. Saito, H., and K. Miura. 1963. Preparation of transforming deoxyribonucleic acid by phenol treatment. Biochim. Biophys. Acta 72:619-629.

37. Saitou, N., and M. Nei. 1987. The neighbor-joining method: a new method for reconstructing phylogenetic trees. Mol. Biol. Evol. 4:406-425.

38. Sneath, P. H. A., and R. R. Sokal. 1973. Numerical taxonomy. W. H. Freeman \& Co., San Francisco.

39. Staneck, J. L., and G. D. Roberts. 1974. Simplified approach to identification of aerobic actinomycetes by thin-layer chromatography. Appl. Microbiol. 28:226-231.

40. Stevenson, I. L. 1967. Utilization of aromatic hydrocarbons by Arthrobacter spp. Can. J. Microbiol. 13:205-211.

41. Suzuki, K., and K. Komagata. 1983. Taxonomic significance of cellular fatty acid composition in some coryneform bacteria. Int. J. Syst. Bacteriol. 33:188-200.

42. Tamaoka, J., Y. Katayama-Fujimura, and H. Kuraishi. 1983. Analysis of bacterial menaquinone mixtures by high performance liquid chromatography. J. Appl. Bacteriol. 54:31-36.

43. Tamaoka, J., and K. Komagata. 1984. Determination of DNA base composition by reversed-phase high-performance liquid chromatography. FEMS Microbiol. Lett. 25:125-128.

44. Tomiyasu, I. 1982. Mycolic acid composition and thermally adaptative changes in Nocardia asteroides. J. Bacteriol. 151: 828-837.

45. Uchida, K., and K. Aida. 1984. An improved method for the glycolate test for simple identification of the acyl type of bacterial cell walls. J. Gen. Appl. Microbiol. 30:131-134.

46. Yamada, Y., G. Inouye, Y. Tahara, and K. Kondo. 1977. On the chemical structure of menaquinones with the tetrahydrogenated isoprenoid side chain. Biochim. Biophys. Acta 486:195-203. 